\author{
Review Article \\ www.ijrap.net (ISSN:2229-3566)
}

\title{
TUTTHA SHODHANA: CLASSICAL VIEW AND SCIENTIFIC REVIEW
}

Jayalaxmi *1, MS Krishnamurthy ${ }^{2}$, Chaitra $\mathrm{LV}^{3}$

${ }^{1} \mathrm{PhD}$ Scholar and Associate Professor, Department of Rasa shastra and Bhaishajya Kalpana, Sri Siddarameshwara Ayurvedic Medical College, Bidar, Karnataka, India

${ }^{2}$ Dean and HOD, Department of Rasa shastra and Bhaishajya Kalpana, Alvas Ayurveda Medical College Moodbidri, Mangalore, Karnataka, India

${ }^{3}$ PhD Scholar and Associate Professor, Department of Rasa shastra and Bhaishajya Kalpana, Ramakrishna Ayurvedic Medical College, Bangalore, Karnataka, India

Received on: 19/04/21 Accepted on: 17/06/21

\author{
*Corresponding author \\ E-mail: drjayalaxmim@gmail.com
}

DOI: 10.7897/2277-4343.120377

\begin{abstract}
Rasa dravyas which are crude, are always subjected to many classical operative procedures before it used as a medicine, be it a metal, mineral or any other crude toxic drug. The aim of the Shodhana (detoxifying procedure) etc. procedures is to produce safe and effective medicine. Tuttha being one such rasa dravya a member of Maharasa varga and upadhatu of tamra is having a peculiar combination of nectar and poison mythologically, also subjected for different classical procedures like nirmalikarana (cleaning measures), Shodhana (procedures which removes blemishes) and Marana (incineration), Satwapatana (extractive procedures), so that it can be utilized in different forms for various therapeutic needs. So an attempt is made to review such Shodhana procedures through which crude drug Tuttha coverts into potent therapeutic drug and probable scientific aspects behind the media and method of Shodhana are dealt here.
\end{abstract}

Keywords: Tuttha, Shodhana, Visha, Bhavana, Mardana.

\section{INTRODUCTION}

Tuttha $6^{\text {th }}$ Maharasa ${ }^{1}$ dravya is considered as copper sulphate in English. Mythologically it is considered as vomitus of Garuda deva (Goddess) ${ }^{2}$; after drinking amrita and halahala (toxic substance), Garuda deva vomited on the mountain of marakata (name of mountain). There after this vomitus, the combination of amrita and visha solidified and collected as Tuttha. It is also called as Tuttha, Tutthanjana, Mayuraka, Tamragarbha, Shikhigreeva ${ }^{3}$ etc. It is available in natural and manufactured artificially with the combination of copper and sulphur. The Tuttha having shikhikantha chaya (like peacock neck color), neela varna (bluish color), guru (heavy), snigdha (unctuous), mahojwala (bright) ${ }^{4}$ qualities, is to be considered for therapeutic purpose. The review of literatures carried out by referring different available Rasa shastra texts. Tuttha if not subjected for Shodhanadi procedures it may produce vanti (vomiting), bhranti (dilemma) etc. Therefore, it is subjected for Shodhana before using for therapeutic purpose. Such Shodhana procedures are reviewed here.

\section{Nirmalikarana}

Rasa taranginikara subjects Tuttha for nirmalikarana ${ }^{5}$ before subjecting for Shodhana.

10 parts of Tuttha is taken and is mixed with 5 parts of hot water, stirred well, then filtered through filter paper, collected in glass flask, this glass flask is kept stable without disturbing until granular form of Tuttha settles down at the bottom of the flask. This Tuttha can be utilized for external applications. For internal administration it should be subjected for Shodhana etc. procedures.

The Nirmalikrita Tuttha is meant for external application.

\section{Shodhana}

For internal administration, Tuttha is subjected for different Shodhana methods like Mardana (pounding), Bhavana (trituration), Nirvapana (quenching), Nimajjana (soaking), Swedana (drug tied in a cloth and boiling in a liquid media) and Bhasmikarana (incineration) as per therapeutic need. Like Mardana with Nimbu Swarasa (Table 1). Bhavana in raktachandana kashaya and manjishta kashaya and also in amla varga dravya and Rakta varga dravya is done respectively (Table 2). It is also processed through go, aja mahisha and naramutra in Swedana procedure (Table 3). The specificity of Swedana is that here pottaligata (cloth bundle containing drugs) dravya will be discarded and the drava-dravya gata (liquid media) Tuttha will be collected as purified one. It is subjected for Nimajjana in Sneha varga dravya and Gomutra (Table 4) to get it purified. The Tuttha is also subjected for puta to get it purified with the Marana dravyas like marjara vista, kapota vista with combination of tankana, madhu, dadhi in different ratio (Table 5). Tapana is also the method of Shodhana with the ingredients like dadhi (Table 6).

Table 1: Shodhana of Tuttha by Mardana method

\begin{tabular}{|c|c|c|}
\hline Method & Ingredients & Duration \\
\hline Mardana $^{6}$ & Nimbu Swarasa & 2 Yama \\
\hline
\end{tabular}


Jayalaxmi et al / Int. J. Res. Ayurveda Pharm. 12 (3), 2021

Table 2: Shodhana of Tuttha by Bhavana method

\begin{tabular}{|c|c|c|}
\hline Method & Ingredients & Number \\
\hline Bhavana $^{7}$ & Raktachandana kashaya and Manjishta kashaya & 7 Bhavana \\
\hline Bhavana $^{8}$ & Amla varga dravya & 7 Bhavana \\
\hline Bhavana $^{9}$ & Rakta varga dravya & 7 Bhavana \\
\hline
\end{tabular}

Table 3: Shodhana of Tuttha by Swedana method

\begin{tabular}{|c|c|c|c|}
\hline Method & Drava dravya & Procedure & Duration \\
\hline Swedana $^{10}$ & Gomutra & $\begin{array}{c}\text { After Swedana, Pottali discarded and Gomutra boiled till little moisture remains. After swanga } \\
\text { Sheeta, Tuttha collected from the bottom of vessel in granular form. }\end{array}$ & 3 Yama \\
\hline Swedana $^{11}$ & Mahisha Mutra & $\begin{array}{l}\text { After Swedana, Pottali discarded and Mahisha Mutra boiled till littlemoisture remains. After } \\
\text { swanga sheeta, Tuttha collected from the bottom of vessel in granular form. }\end{array}$ & 3 Prahara \\
\hline Swedana $^{12}$ & Aja Mutra & $\begin{array}{l}\text { After Swedana, Pottali discarded, and Aja Mutra boiled till little moisture remains. After swanga } \\
\text { sheeta, Tuttha collected from the bottom of vessel in granular form. }\end{array}$ & 3 Prahara \\
\hline Swedana $^{13}$ & Nara Mutra & $\begin{array}{c}\text { After Swedana, Pottali discarded, and Aja Mutra boiled till little moisture remains. After swanga } \\
\text { sheeta, Tuttha collected from the bottom of vessel in granular form. }\end{array}$ & 3 Prahara \\
\hline
\end{tabular}

Table 4: Shodhana of Tuttha by Nimajjana method

\begin{tabular}{|c|c|c|}
\hline Method & Ingredients & Duration \\
\hline Nimajjana $^{14}$ & Sneha varga dravya & 7 times \\
\hline Nimajjana $^{15}$ & Gomutra & 7 times \\
\hline
\end{tabular}

Table 5: Shodhana of Tuttha by Puta method

\begin{tabular}{|c|c|c|}
\hline Method & Ingredients & Puta \\
\hline Puta $^{16}$ & Marjara and kapota vista Mardana $+1 / 10 \mathrm{p}$ Tankana. Succeeding puta with dadhi and madhu Mardana. & Laghu puta \\
\hline Puta $^{17}$ & Kapota vishta and honey $+1 / 4 \mathrm{p}$ Tankana Mardana & 3 Laghu puta \\
\hline Puta $^{18}$ & Mardana with marjara and kapotavista $+1 / 10 \mathrm{p}$ tankana & Laghu puta \\
\cline { 2 - 4 } & Followed by Dadhi Mardana & 1 Laghu puta \\
\cline { 2 - 4 } & Followed by Madhu Mardana & 1 Laghu puta \\
\hline Puta $^{19}$ & Mardana with marjara vista added with equal part of madhu, $1 / 4^{\text {th }}$ part of tankana & 3 puta \\
\hline
\end{tabular}

Table 6: Shodhana of Tuttha by Tapana (Heating) method

\begin{tabular}{|c|c|}
\hline Method & Ingredients \\
\hline Tapana $^{20}$ & Mardana with dadhi - Chakrika Nirmana, placed over earthen plate. \\
\hline
\end{tabular}

\section{DISCUSSION}

The different methods are adopted for Tuttha Shodhana like Mardana, Bhavana, Nimajjana, Nirvapana and Swedana, puta all will produce Shodhita Tuttha. The specificity of Tuttha is that it can be used externally after Nirmalikarana and can also be utilized for internally administration in Shodhita avastha.

After referring available research articles ${ }^{21}$, one can observe that the Tuttha subjected for Shodhana after nirmalikarana differs in its concentration of elements in it. The Nirmalikrita Tuttha found crystalline blue with green tinge, Tikta rasa and metallic smell. The concentration of sulphur varies from 14.70 in ashodhita Tuttha to 9.46 in Nirmalikrita Shodhita Tuttha. The iron 0.83 to 0.98 in Nirmalikrita and in Nirmalikrita and Nimbu Swarasa Shodhita Tuttha $1.09 \%$ and copper was found $81.15 \%$ to $87.61 \%$, the concentration of zinc reduced from 1.70 to $0.68 \%$ the potassium $0.17 \%$ found in ashodhita was not detected in Nirmalikrita Shodhita Tuttha. By analysis of available research article one can claim that Tuttha when processed for Shodhana after nirmalikarana the concentration of sulphur decreased, and copper and iron concentration was found increased notably. The texture opaque rough blue was turned to crystalline blue tinge in Nirmalikrita and Nirmalikrita Shodhita was found powder form and sea green color. And lemon smell (may vary based on Shodhana method adopted). The sulphur concentration too reduced.
The methods may vary for Shodhana, like other drugs it can also be used as Tuttha Bhasma, Satwa too internally. So the total utility of Tuttha is in 5 forms, Nirmalikrita Tuttha for externally, Shodhita, Marita, Satwa of Tuttha for internal purpose and also ashodhita Tuttha can be used for inducing vomiting in toxic conditions. The dosage of Shodhita Tuttha formulation varies from 1-2 ratti ${ }^{22}$. But Marita Tuttha Matra decreases up to $1 / 8$ to $1 / 4$ gunja $^{23}$ and Satwa as that of tamra i.e. $1 / 8-1 / 2$ ratti $^{24}$. The crude metals or minerals when subjected for different operative procedures like Mardana, Nirvapana etc. will convert the crude one into therapeutically beneficial drugs. So, when visha and amrita combine and processed as per classical guidelines, it will be highly beneficial as Rasaratna samuchyakara quotes while explaining Tuttha.

\section{CONCLUSION}

The $6^{\text {th }}$ Maharasa dravya and upadhatu of tamra, mythologically visha -amrita combination has different references for Shodhana methods in classical rasa texts, there it may be used in varied therapeutic conditions and in various forms like ashodhita, Nirmalikrita, Shodhita, Marita and Satwa form. Such different methods should be subjected for analytical study and further screening to know the variation in Shodhita Tuttha qualities after adopting different methods, for its exclusive therapeutic indications. Various forms of Shodhita Tuttha if subjected for multi centric clinical study; may yield a safe and potent drug in different therapeutic conditions. 


\section{REFERENCES}

1. Shree Vagbhata Acharya, Rasaratna Samuchchaya, Commentary by Dattatreya Ananta Kulkarni, Meharchand Lachmandas Publications, 2/1. p. 18.

2. Shree Vagbhata Acharya, Rasaratna Samuchchaya, Commentary by Dattatreya Ananta Kulkarni, Meharchand Lachmandas Publications, 2/ 125-126. p. 36.

3. Sadananda Sharma, Rasa Tarangini, Edited by Kashinatha Shastri, Varanasi, Motilal Banarasi Das Publications, 21/ 71. p. 533.

4. Sadananda Sharma, Rasa Tarangini, Edited by Kashinatha Shastri, Varanasi, Motilal Banarasi Das, Publications, 21/ 72. p. 534.

5. Sadananda Sharma, Rasa Tarangini, Edited by Kashinatha Shastri, Varanasi, Motilal Banarasi Das, Publications, 21/ 7375. p. 534.

6. Sadananda Sharma, Rasa Tarangini, Edited by Kashinatha Shastri, Varanasi, Motilal Banarasi Das Publications, 21/106107. p. 540.

7. Sadananda Sharma, Rasa Tarangini, Edited by Kashinatha Shastri, Varanasi, Motilal Banarasi Das Publications, 21/ 108. p. 540 .

8. Sadananda Sharma, Rasa Tarangini, Edited by Kashinatha Shastri, Varanasi, Motilal Banarasi Das, Publications, 21/ 112. p. 541.

9. Shree Vagbhata Acharya, Rasaratna Samuchchaya, Commentary by Dattatreya Ananta Kulkarni, New Delhi, Meharchand Lachmandas Publications, 2/ 129. p. 37.

10. Shree Vagbhata Acharya, Rasaratna Samuchchaya, Commentary by Dattatreya Ananta Kulkarni, New Delhi, Meharchand Lachmandas Publications; 1998, 2/129. p. 37.

11. Shree Vagbhata Acharya, Rasaratna Samuchchaya, Commentary by Dattatreya Ananta Kulkarni, New Delhi, Meharchand Lachmandas Publications, 2/129. p. 37.

12. Shree Vagbhata Acharya, Rasaratna Samuchchaya, Commentary by Dattatreya Ananta Kulkarni, New Delhi, Meharchand Lachmandas Publications; 1998, 2/129. p. 37.
13. Siddhinandan Mishra, Rasendra chudamani, Varanasi, Chaukhambha Orientalia,75. p. 152.

14. Shree Vagbhata Acharya, Rasaratna Samuchchaya, Commentary by Dattatreya Ananta Kulkarni, New Delhi, Meharchand Lachmandas Publications, 2/ 129. p. 37.

15. Vaidya Yadavaji Trikamaji Acharya, Siddhayoga Sangraha, Nagpur, Shree Baidyanath Ayurveda Bhavan Ltd publications. p. 172.

16. Acharya Madhava, Ayurveda Prakasha, Gulraj Sharma Mishra Varanasi, Chaukhambha Bharati Academy, 3/40. p. 417.

17. Shree Vagbhata Acharya, Rasaratna Samuchchaya, Commentary by Dattatreya Ananta Kulkarni New Delhi, Meharchand Lachmandas Publications, 41. p. 418.

18. Shree Laxmipati Shastri, Yogaratnakara, Varanasi, Chaukhambha Prakashan, Shloka 1. p. 148.

19. Shree Laxmipati Shastri, Yogaratnakara, Varanasi, Chaukhambha Prakashan, Reprint; 2009. p. 148.

20. Prof. M. S. Krishnamurthy, Basavarajeeyam, Varanasi, Chaukhambha Orientalia publications, 25/187. p. 669.

21. Mahapatra A \& Mahapatra B. Role of Shodhana on Antimicrobial Activity of Tuttha. International Journal of Ayurvedic Medicine 2013; 4(3). https://doi.org, 10.47552,ijam.v4i3.338.

22. Sadananda Sharma, Rasa Tarangini, Edited by Kashinatha Shastri, Varanasi, Motilal Banarasi Das, 21/114. p. 541.

23. Sadananda Sharma, Rasa Tarangini, Edited by Kashinatha Shastri, Varanasi, Motilal Banarasi Das, publications 21/ 130. p. 543.

24. Sadananda Sharma, Rasa Tarangini, Edited by Kashinatha Shastri, Varanasi, Motilal Banarasi Das, 21/ 144. p. 546.

\section{Cite this article as:}

Jayalaxmi et al. Tuttha Shodhana: Classical view and Scientific Review. Int. J. Res. Ayurveda Pharm. 2021;12(3):73-75 http://dx.doi.org/10.7897/2277-4343.120377

Disclaimer: IJRAP is solely owned by Moksha Publishing House - A non-profit publishing house, dedicated to publishing quality research, while every effort has been taken to verify the accuracy of the content published in our Journal. IJRAP cannot accept any responsibility or liability for the site content and articles published. The views expressed in articles by our contributing authors are not necessarily those of IJRAP editor or editorial board members. 